\title{
Iodothyronine Release from the Perfused Canine Thyroid following Cessation of Stimulation
}

\author{
RAPID DECLINE OF TRIIODOTHYRONINES IN COMPARISON \\ WITH THYROXINE
}

\author{
Peter Laurberg, Second University Clinic of Internal Medicine, \\ Kommunehospitalet, DK-8000 Aarhus C, Denmark
}

\begin{abstract}
A B S T R A C T The kinetics of thyroid secretion after termination of stimulation by $100 \mu \mathrm{U} / \mathrm{ml}$ bovine thyroid stimulating hormone (TSH) or $5 \mathrm{mM}$ cyclic AMP (cAMP) were studied using perfused canine thyroid lobes. All experiments were performed as paired comparisons, one thyroid lobe acting as a control continuing to receive infusion of the stimulator. $2.5 \mathrm{~h}$ after termination of TSH infusion, the secretion of thyroxine $\left(\mathrm{T}_{4}\right), 3,5,3^{\prime}$-triiodothyronine $\left(\mathrm{T}_{3}\right)$, and $3,3^{\prime}, 5^{\prime}$ triiodothyronine $\left(\mathrm{rT}_{3}\right)$ was not significantly different from that of the control lobes. After cessation of cAMP infusion, the secretion of $\mathrm{T}_{4}$ continued unaffected for $\sim 40 \mathrm{~min}$. Then a gradual decline in $\mathrm{T}_{4}$ release occurred. The secretion of $\mathrm{T}_{3}$ and $\mathrm{rT}_{3}$ decreased somewhat earlier leading to a transient phase with increases in the $\mathrm{T}_{4}: \mathrm{T}_{3}$ and $\mathrm{T}_{4}: \mathrm{rT}_{3}$ ratios in the thyroid effluent.
\end{abstract}

The persistently high secretion of iodothyronines despite cessation of TSH infusion is most likely the result of a continued stimulation by receptor-bound TSH. Because the clearance of intracellular cAMP is rapid and the concentration of cAMP used for stimulation in these experiments only exceeded the concentration necessary for eliciting a secretory response modestly, it is reasonable to assume that stimulation of colloid droplet formation stopped shortly after termination of cAMP infusion. The bulk of iodothyronines secreted thereafter thus originated from continued hydrolysis of thyroglobulin engulfed by the follicular cells during the preceding cAMP infusion. The pattern of an earlier decline in secretion of $\mathrm{T}_{3}$ and $\mathrm{rT}_{3}$ than of $\mathrm{T}_{4}$ from this intracellular pool of thyroglobulin points to a more rapid liberation of tri-

Received for publication 26 July 1979 and in revised form 25 September 1979. iodothyronines than of thyroxine from thyroglobulin during intracellular hydrolysis.

\section{INTRODUCTION}

The use of specific and sensitive radioimmunoassays for quantitation of iodothyronine release from perfused thyroid lobes has revealed that iodothyronines are secreted from the thyroid in mutual proportions quite different from those found in hydrolysate of thyroid tissue, and that stimulation of thyroid secretion induces alterations in the relative proportions of various iodothyronines in secretion $(1-3)$. In view of the different biological activities of thyroxine $\left(T_{4}\right)^{1}$ and $3,5,3^{\prime}$-triiodothyronine $\left(\mathrm{T}_{3}\right)$, it is important to elucidate in detail the mechanisms whereby the composition of thyroid secretion is altered and to learn the secretory pattern in various functional states of the thyroid gland.

In the present study we measured $\mathrm{T}_{4}, \mathrm{~T}_{3}$, and $3,3^{\prime}, 5^{\prime}$ triiodothyronine (reverse $\mathrm{T}_{3}, \mathrm{rT}_{3}$ ) in thyroid effluent after cessation of stimulation with thyroid stimulating hormone (TSH) or cyclic AMP (cAMP). The method used for the experiments, as in other studies presented earlier, is a once-through perfusion of isolated thyroid lobes with a hormone-free medium. This technique permits more accurate and dependable estimations of the kinetics of thyroid secretion than in vivo studies, which are hampered by the problems of recirculation of stimulators and previously secreted iodothyronines. Furthermore, the delays in diffusion inherent in studies of thyroid slices or incubated lobes are also avoided in the present model

${ }^{1}$ Abbreviations used in this paper: cAMP, cyclic AMP; $\mathrm{rT}_{3}, 3,3^{\prime}, 5^{\prime}$-triiodothyronine; $\mathrm{T}_{4}$, thyroxine; TSH, thyroidstimulating hormone; $\mathrm{T}_{3}, 3,3^{\prime}, 5^{\prime}$-triiodothyronine. 
because stimulators and secretory products are transported via the circulation.

\section{METHODS}

Two-sided thyroid perfusions were performed in 10 mongrel dogs weighing $20-28 \mathrm{~kg}$. Individual data on weight and iodothyronine content of thyroid lobes are given in Tables I and II. The technique has been described in detail earlier $(1,2)$. In brief, the two separate thyroid lobes are isolated in situ in such a way that perfusion medium pumped into an isolated segment of each common carotid artery can be collected quantitatively from each thyroid lobe through catheters in the internal jugular veins. The $\operatorname{dog}$ is exsanguinated after the insertion of the afferent catheters. The perfusion medium is a modified Krebs-Ringer bicarbonate buffer containing $4 \%$ dextran $(70,000 \mathrm{~mol} \mathrm{wt})$. The flow rate for each thyroid lobe is $0.63 \mathrm{ml} / \mathrm{min}$. The perfusion pressure was constant throughout the experiments at $30-40 \mathrm{~mm} \mathrm{Hg}$. The total effluent from 5-min intervals was collected. In all experiments $100 \mu \mathrm{U} / \mathrm{ml} \mathrm{TSH}$ or $5 \mathrm{mM}$ CAMP was infused in both thyroid lobes as soon as both of the afferent catheters had been inserted in the common carotid arteries, i.e., TSH or cAMP were infused for $-20 \mathrm{~min}$ while the dog was exsanguinated and the efferent catheters were inserted in the internal jugular veins. As soon as the first effluent sample for determination of iodothyronines had been obtained after $30 \mathrm{~min}$ of perfusion in the final setup (the equilibration period generally employed in this model [1]), one thyroid lobe was switched to control medium perfusion for the rest of the perfusion period while the other continued to receive TSH or CAMP. Shift to control medium was performed alternately in the left and right thyroid lobe. After $200 \mathrm{~min}$ of perfusion both thyroid lobes were removed and hydrolysed with pronase using the method of Inoue and Taurog (4) as earlier emploved (3).

TABLE I

$T_{4}, T_{3}$, and $r T_{3}$ in Thyroid Effluent and Hydrolysate following TSH Stimulation

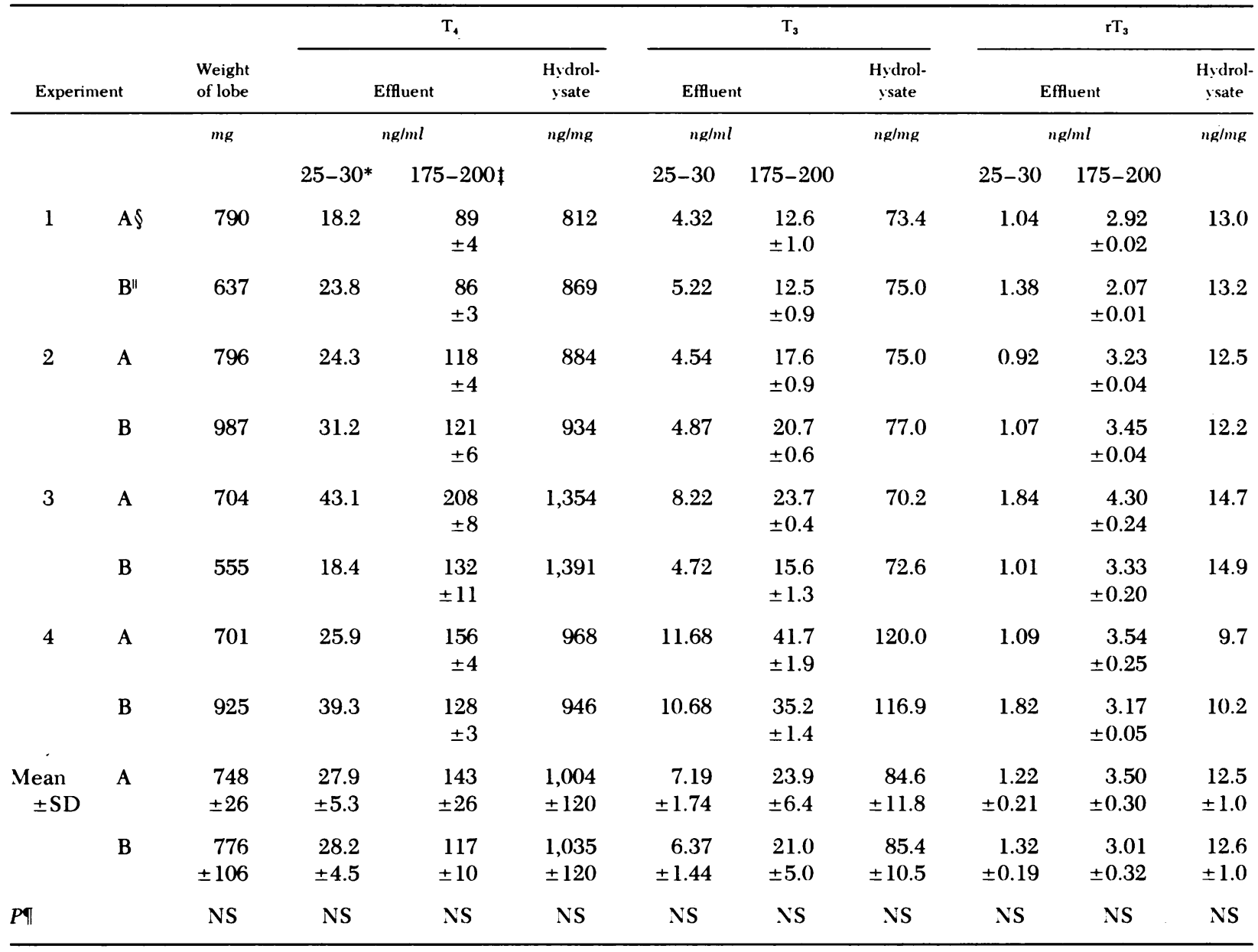

* Sample obtained during the 25-30-min interval of perfusion.

$\$$ Mean \pm SD of three samples obtained during the 175-200-min interval of perfusion.

\$ Lobe receiving $100 \mu \mathrm{U} / \mathrm{ml}$ TSH throughout the experimental period.

" Lobe receiving $100 \mu \mathrm{U} / \mathrm{ml}$ TSH until $30 \mathrm{~min}$ of perfusion.

If $N S=P>0.05$ (paired $t$ test). 
TABLE II

$T_{4}, T_{3}$, and $r T_{3}$ in Thyroid Effluent and Hydrolysate following cAMP Stimulation

\begin{tabular}{|c|c|c|c|c|c|c|c|c|c|c|c|c|c|c|}
\hline & & \multirow[b]{2}{*}{$\begin{array}{l}\text { Weight } \\
\text { of lobe }\end{array}$} & \multicolumn{4}{|c|}{$\mathrm{T}_{4}$} & \multicolumn{4}{|c|}{$\mathrm{T}_{3}$} & \multicolumn{4}{|c|}{$\mathrm{rT}_{3}$} \\
\hline \multicolumn{2}{|c|}{ Experiment } & & & Effluent & & $\begin{array}{l}\text { Hydrol- } \\
\text { ysate }\end{array}$ & & Effluent & & $\begin{array}{l}\text { Hydrol- } \\
\text { ysate }\end{array}$ & & Effluent & & $\begin{array}{l}\text { Hydrol- } \\
\text { ysate }\end{array}$ \\
\hline \multirow{4}{*}{1} & & $m g$ & & $n g / m l$ & & $n g / m g$ & & $n g / m l$ & & $n g / m g$ & & $n g / m l$ & & $n g / m g$ \\
\hline & & & $25-30^{*}$ & $65-90\rfloor$ & $175-200 t$ & & $25-30$ & $65-90$ & $175-200$ & & $25-30$ & $65-90$ & $175-200$ & \\
\hline & $A \S$ & 965 & 16.8 & $\begin{array}{r}78.4 \\
\pm 12.6\end{array}$ & $\begin{array}{r}55.1 \\
\pm 3.5\end{array}$ & 658 & 3.96 & $\begin{array}{r}19.1 \\
\pm 2.1\end{array}$ & $\begin{array}{r}14.7 \\
\pm 0.7\end{array}$ & 83.1 & 1.31 & $\begin{array}{r}3.73 \\
\pm 0.16\end{array}$ & $\begin{array}{r}2.35 \\
\pm 0.29\end{array}$ & 14.1 \\
\hline & $\mathrm{B}^{\prime \prime}$ & 1,148 & 20.0 & $\begin{array}{r}70.1 \\
\pm 1.2\end{array}$ & $\begin{array}{r}11.3 \\
\pm 0.4\end{array}$ & 639 & 6.93 & $\begin{array}{r}11.7 \\
\pm 0.6\end{array}$ & $\begin{array}{r}4.4 \\
\pm 0.4\end{array}$ & 73.0 & 1.10 & $\begin{array}{r}3.02 \\
\pm 0.45\end{array}$ & $\begin{array}{r}0.70 \\
\pm 0.08\end{array}$ & 12.7 \\
\hline \multirow[t]{2}{*}{2} & A & 722 & 5.0 & $\begin{array}{r}26.1 \\
\pm 3.4\end{array}$ & $\begin{array}{r}24.1 \\
\pm 2.7\end{array}$ & 1,030 & 1.27 & $\begin{array}{r}4.0 \\
\pm 0.3\end{array}$ & $\begin{array}{r}4.5 \\
\pm 0.1\end{array}$ & 83.9 & 0.46 & $\begin{array}{r}0.94 \\
\pm 0.09\end{array}$ & $\begin{array}{r}0.94 \\
\pm 0.11\end{array}$ & 16.9 \\
\hline & B & 767 & 12.2 & $\begin{array}{r}43.1 \\
\pm 2.9\end{array}$ & $\begin{array}{c}3.2 \\
\pm 0.2\end{array}$ & 1,076 & 3.33 & $\begin{array}{r}5.0 \\
\pm 1.1\end{array}$ & $\begin{array}{r}0.9 \\
\pm 0.1\end{array}$ & 83.5 & 0.71 & $\begin{array}{r}1.37 \\
\pm 0.27\end{array}$ & $\begin{array}{r}0.19 \\
\pm 0.02\end{array}$ & 19.1 \\
\hline \multirow[t]{2}{*}{3} & A & 726 & 10.7 & $\begin{array}{r}74.4 \\
\pm 21.8\end{array}$ & $\begin{array}{r}68.9 \\
\pm 4.1\end{array}$ & 658 & 2.76 & $\begin{array}{r}11.1 \\
\pm 1.1\end{array}$ & $\begin{array}{r}12.4 \\
\pm 0.5\end{array}$ & 63.3 & 0.90 & $\begin{array}{r}2.85 \\
\pm 0.17\end{array}$ & $\begin{array}{r}2.38 \\
\pm 0.11\end{array}$ & 12.3 \\
\hline & B & 776 & 10.4 & $\begin{array}{r}64.9 \\
\pm 2.3\end{array}$ & $\begin{array}{r}12.6 \\
\pm 2.5\end{array}$ & 884 & 2.40 & $\begin{array}{r}9.1 \\
\pm 0.2\end{array}$ & $\begin{array}{r}2.7 \\
\pm 0.2\end{array}$ & 73.4 & 0.82 & $\begin{array}{r}1.85 \\
\pm 0.10\end{array}$ & $\begin{array}{r}0.66 \\
\pm 0.05\end{array}$ & 13.3 \\
\hline \multirow[t]{2}{*}{4} & A & 711 & 8.4 & $\begin{array}{r}100.0 \\
\pm 9.3\end{array}$ & $\begin{array}{r}67.6 \\
\pm 12.4\end{array}$ & 714 & 5.04 & $\begin{array}{r}22.6 \\
\pm 2.5\end{array}$ & $\begin{array}{r}21.9 \\
\pm 2.3\end{array}$ & 84.7 & 0.70 & $\begin{array}{r}3.31 \\
\pm 0.08\end{array}$ & $\begin{array}{r}2.48 \\
\pm 0.42\end{array}$ & 11.4 \\
\hline & B & 653 & 11.7 & $\begin{array}{r}114.9 \\
\pm 8.1\end{array}$ & $\begin{array}{r}7.3 \\
\pm 1.5\end{array}$ & 696 & 6.10 & $\begin{array}{r}19.4 \\
\pm 0.6\end{array}$ & $\begin{array}{r}4.5 \\
\pm 0.7\end{array}$ & 80.7 & 0.92 & $\begin{array}{r}3.62 \\
\pm 0.27\end{array}$ & $\begin{array}{r}0.34 \\
\pm 0.03\end{array}$ & 10.4 \\
\hline \multirow[t]{2}{*}{5} & A & 950 & 1.7 & $\begin{array}{r}24.3 \\
\pm 8.8\end{array}$ & $\begin{array}{r}51.1 \\
\pm 5.2\end{array}$ & 1,034 & 0.60 & $\begin{array}{r}8.8 \\
\pm 2.0\end{array}$ & $\begin{array}{r}12.6 \\
\pm 0.7\end{array}$ & 111.2 & 0.13 & $\begin{array}{r}1.08 \\
\pm 0.26\end{array}$ & $\begin{array}{r}1.29 \\
\pm 0.08\end{array}$ & 16.9 \\
\hline & B & 850 & 1.9 & $\begin{array}{r}29.0 \\
\pm 1.8\end{array}$ & $\begin{array}{r}4.7 \\
\pm 0.5\end{array}$ & 978 & 0.70 & $\begin{array}{r}3.3 \\
\pm 0.3\end{array}$ & $\begin{array}{r}1.3 \\
\pm 0.1\end{array}$ & 112.8 & 0.17 & $\begin{array}{r}0.74 \\
\pm 0.03\end{array}$ & $\begin{array}{r}0.19 \\
\pm 0.01\end{array}$ & 14.5 \\
\hline \multirow[t]{2}{*}{6} & A & 644 & 10.8 & $\begin{array}{r}52.0 \\
\pm 1.9\end{array}$ & $\begin{array}{r}72.2 \\
\pm 3.2\end{array}$ & 382 & 2.92 & $\begin{array}{r}10.4 \\
\pm 0.4\end{array}$ & $\begin{array}{r}15.7 \\
\pm 1.7\end{array}$ & 40.3 & 0.54 & $\begin{array}{r}1.36 \\
\pm 0.19\end{array}$ & $\begin{array}{r}1.49 \\
\pm 0.09\end{array}$ & 3.8 \\
\hline & B & 520 & 8.7 & $\begin{array}{r}32.5 \\
\pm 5.2\end{array}$ & $\begin{array}{r}2.7 \\
\pm 0.1\end{array}$ & 291 & 2.88 & $\begin{array}{r}4.0 \\
\pm 0.4\end{array}$ & $\begin{array}{r}0.9 \\
\pm 0.2\end{array}$ & 31.0 & 0.52 & $\begin{array}{r}0.64 \\
\pm 0.09\end{array}$ & $\begin{array}{r}0.09 \\
\pm 0.01\end{array}$ & 2.6 \\
\hline \multirow[t]{2}{*}{$\begin{array}{l}\text { Mean } \\
\quad \pm \text { SD }\end{array}$} & A & $\begin{array}{r}786 \\
\pm 56\end{array}$ & $\begin{array}{r}8.1 \\
\pm 2.1\end{array}$ & $\begin{array}{r}59.2 \\
\pm 12.4\end{array}$ & $\begin{array}{r}56.5 \\
\pm 7.3\end{array}$ & $\begin{array}{r}746 \\
\pm 102\end{array}$ & $\begin{array}{r}2.76 \\
\pm 0.67\end{array}$ & $\begin{array}{r}12.7 \\
\pm 2.8\end{array}$ & $\begin{array}{r}13.6 \\
\pm 2.3\end{array}$ & $\begin{array}{r}77.8 \\
\pm 9.7\end{array}$ & $\begin{array}{r}0.67 \\
\pm 0.16\end{array}$ & $\begin{array}{r}2.21 \\
\pm 0.50\end{array}$ & $\begin{array}{r}1.82 \\
\pm 0.27\end{array}$ & $\begin{array}{r}12.6 \\
\pm 2.0\end{array}$ \\
\hline & B & $\begin{array}{r}786 \\
\pm 86\end{array}$ & $\begin{array}{r}10.8 \\
\pm 2.4\end{array}$ & $\begin{array}{r}59.1 \\
\pm 13.1\end{array}$ & $\begin{array}{r}7.0 \\
\pm 1.7\end{array}$ & $\begin{array}{r}761 \\
\pm 116\end{array}$ & $\begin{array}{r}3.72 \\
\pm 0.96\end{array}$ & $\begin{array}{r}8.8 \\
\pm 2.5\end{array}$ & $\begin{array}{r}2.4 \\
\pm 0.7\end{array}$ & $\begin{array}{r}75.7 \\
\pm 10.8\end{array}$ & $\begin{array}{r}0.71 \\
\pm 0.13\end{array}$ & $\begin{array}{r}1.87 \\
\pm 0.50\end{array}$ & $\begin{array}{r}0.36 \\
\pm 0.11\end{array}$ & $\begin{array}{r}12.1 \\
\pm 2.2\end{array}$ \\
\hline$P \mathbb{9}$ & & NS & NS & NS & $<0.001$ & NS & NS & $<0.05$ & $<0.01$ & NS & NS & NS & $<0.001$ & NS \\
\hline
\end{tabular}

* Sample obtained during the 25-30-min interval of perfusion.

1 Mean \pm SD of three samples obtained during the 65-90- or 175-200-min interval of perfusion.

\$ Lobe receiving cAMP, $5 \mathrm{mM}$ throughout the experimental period.

" Lobe receiving cAMP, $5 \mathrm{mM}$ until $30 \mathrm{~min}$ of perfusion.

I $P$ value, $N S=P>0.05$ (paired $t$ test).

$\mathrm{T}_{4}, \mathrm{~T}_{3}$, and $\mathrm{rT}_{3}$ in effluent samples and ethanol extracts of hydrolysates were measured radioimmunologically $(5,6,3)$. All samples from one experiment were measured in triplicate in the same assay. Bovine TSH for stimulation was the international standard preparation, a gift from the Medical Research Council, London, England. cAMP was obtained from Sigma Chemical Co., St. Louis, Mo.

Calculation of a hypothetical $T_{4}: T_{3}$ ratio in thyroid effluent. For the elucidation of the results obtained in the experiments presented here, it was interesting to calculate a hypothetical variation in the $T_{4}: T_{3}$ ratio in thyroid effluent using data from four previous thyroid perfusion experiments (3). In these experiments iodothyronines in effluent were measured at short intervals (every $10 \mathrm{~min}$ ) throughout the experiments. Four control samples were obtained (after 30,40,
50 , and $60 \mathrm{~min}$ of perfusion), then $100 \mu \mathrm{U} / \mathrm{ml} \mathrm{TSH}$ was infused for $140 \mathrm{~min}$. $T_{4}$ and $T_{3}$ were also measured in pronase hydrolysate of the thyroids. For calculations the following assumptions were made: the $T_{4}: T_{3}$ ratio in thyroglobulin engulfed and hydrolysed during secretion was identical to that measured in pronase hydrolysate of thyroid homogenate; a constant fraction of $\mathrm{T}_{4}$ liberated during intracellular hydrolysis of thyroglobulin was deiodinated to $T_{3}$ during secretion; $\mathrm{T}_{4}$ was released somewhat slower than $\mathrm{T}_{3}$ during hydrolysis of thyroglobulin. In the chosen example the delivery of $75 \%$ of the $T_{4}$ was estimated to be delayed $20 \mathrm{~min}$ in comparison with the $T_{3}$.

During steady-state secretion, this delay in $T_{4}$ release would not affect the $T_{4}: T_{3}$ ratio in thyroid effluent, and differences between the $T_{4}: T_{3}$ ratio in pronase hydrolysate of thyroid 
tissue and in thyroid effluent would be solely the result of $\mathrm{T}_{4}$ monodeiodination to $\mathrm{T}_{3}$. The reason for applying the calculations to the above-mentioned experiments was that the stable period of control perfusion before stimulation was necessary for calculation of $T_{4}$ monodeiodination to $T_{3}$. The difference in the molecular weights of $T_{4}$ and $T_{3}$ was corrected when necessary.

In the following equation:

$$
\text { fraction } \begin{aligned}
\mathrm{T}_{4} \rightarrow \mathrm{T}_{3}= & \left(\text { control } \mathrm{T}_{3 \text { eff }}\right. \\
& \left.-\frac{\text { control } \mathrm{T}_{4 \text { eff }}}{\mathrm{T}_{4} / \mathrm{T}_{3} \text { in thyr }}\right) / \operatorname{control~} \mathrm{T}_{4} \text { eff, }
\end{aligned}
$$

where fraction $T_{4} \rightarrow T_{3}$ is the fraction of liberated $T_{4}$ deiodinated to $T_{3}$ during secretion (assumption 2). Control $T_{3}$ eff and control $\mathrm{T}_{4}$ eff are the mean $\mathrm{T}_{3}$ and $\mathrm{T}_{4}$ concentrations in thyroid effluent during control perfusion. $T_{4}: T_{3}$ in thyr is the $\mathrm{T}_{4}: \mathrm{T}_{3}$ ratio in pronase hydrolysate of thyroid homogenate.

$$
\mathrm{T}_{3}(\mathrm{TG})=\mathrm{T}_{3 \text { eff }}-\left(\text { fraction } \mathrm{T}_{4} \rightarrow \mathrm{T}_{3} \times \mathrm{T}_{4 \text { eff }}\right)
$$

where $T_{3}(T G)$ is the calculated amount of $T_{3}$ in an effluent sample originating from $T_{3}$ in thyroglobulin. $T_{3}$ eff and $T_{4}$ eff are the measured concentrations of $T_{3}$ and $T_{4}$ in the same effluent sample. $T_{3}(\mathrm{TG})$ was calculated for each effluent sample.

$$
\begin{aligned}
& \mathrm{T}_{4} \text { hypot }=\mathrm{T}_{4}: \mathrm{T}_{3} \text { in thyr } \\
& \times\left(0.75 \times \mathrm{T}_{3}[\mathrm{TG}]_{[-20 \mathrm{~min}]}+0.25 \times \mathrm{T}_{3}[\mathrm{TG}]\right)
\end{aligned}
$$

where $T_{4}$ hypot is the hypothetical $T_{4}$ concentration in each sample under the assumption that the delivery of $75 \%$ of $\mathrm{T}_{4}$ is delayed $20 \mathrm{~min}$ to $T_{3}$ during secretion. $T_{3}(T G)_{(-20 \mathrm{~min})}$ is $\mathrm{T}_{3}(\mathrm{TG})$ in the effluent sample obtained $20 \mathrm{~min}$ earlier. $\mathrm{T}_{4}$ hypot was calculated for each sample. The hypothetical $\mathrm{T}_{4} /$ measured $T_{3}$ was then calculated for each sample and the curve compared with the curve drawn from the raw experimental data.

Because the fractional deiodination of $T_{4}$ to $\mathrm{rT}_{3}$ seems to diminish during TSH stimulation (3), such calculations could not be made for $\mathrm{rT}_{3}$. As to the amounts of $\mathrm{T}_{4}$ disappearing during secretion as a result of deiodination to $T_{3}$ and $\mathrm{rT}_{3}$, these cannot be estimated exactly and are not corrected. Judged from the variation in $\mathrm{T}_{4}$ secretion during inhibition of intrathyroidal deiodination (7), this amount of $\mathrm{T}_{4}$ is relatively small compared with the $\mathrm{T}_{4}$ secreted. In the four experiments used for the present calculations, fraction $T_{4} \rightarrow T_{3}$ was calculated to be $4.3,5.0,8.3$, and $11.0 \%$, respectively. Furthermore, a small fraction of $\mathrm{T}_{3}$ also seems to be deiodinated during secretion ${ }^{2}$ that would tend to correct the small error.

Student's $t$ test for paired comparisons was applied for statistical analyses, employing a $5 \%$ limit of significance. For the comparison of ratios the test was applied to the reciprocal ratios: $\mathrm{T}_{3}: \mathrm{T}_{4}$ and $\mathrm{rT}_{3}: \mathrm{T}_{4}$, to avoid the markedly abnormal distribution characteristic of ratios larger than one.

\section{RESULTS}

Thyroid secretion after cessation of TSH infusion. The mean $\mathrm{T}_{4}$ concentrations in effluent from four thyroid lobes that received a constant infusion of 100 $\mu \mathrm{U} / \mathrm{ml} \mathrm{TSH}$ from the beginning of the perfusion and during the full experimental period, and the four

${ }^{2}$ Laurberg, P., unpublished observations. contralateral thyroid lobes that received control medium after $0.5 \mathrm{~h}$ are depicted in Fig. 1 . The $\mathrm{T}_{4}$ secretion was already increasing rapldlly when the first sample for iodothyronine measurements was obtained. The increase was nearly linear for $\sim 1 \mathrm{~h}$, then the curves leveled off, and a slight, gradual decrease in $T_{4}$ release was observed. The shape of the two curves was nearly identical.

Individual data for $\mathrm{T}_{4}, \mathrm{~T}_{3}$, and $\mathrm{rT}_{3}$ in the first sample and in samples obtained at the end of the experiments are given in Table I. There was no significant difference in iodothyronine release either at the start or at the end of the experiment. Thus the cessation of TSH infusion $2.5 \mathrm{~h}$ earlier had not resulted in a decrease in thyroid iodothyronine release.

To investigate whether the cessation of TSH infusion induced alterations in the mutual proportions between various iodothyronines in thyroid effluent, the $T_{4}: T_{3}$ and $T_{4}: \mathrm{rT}_{3}$ ratios were calculated for all samples. Both the $T_{4}: T_{3}$ and the $T_{4}: r T_{3}$ ratios in effluent were always considerably lower in thyroid effluent than in thyroid hydrolysate. The variations in ratios in effluent were similar to those observed during continuous cAMP infusion (Figs. 3 and 5). Cessation of TSH infusion did not induce any discernible alteration in the relative

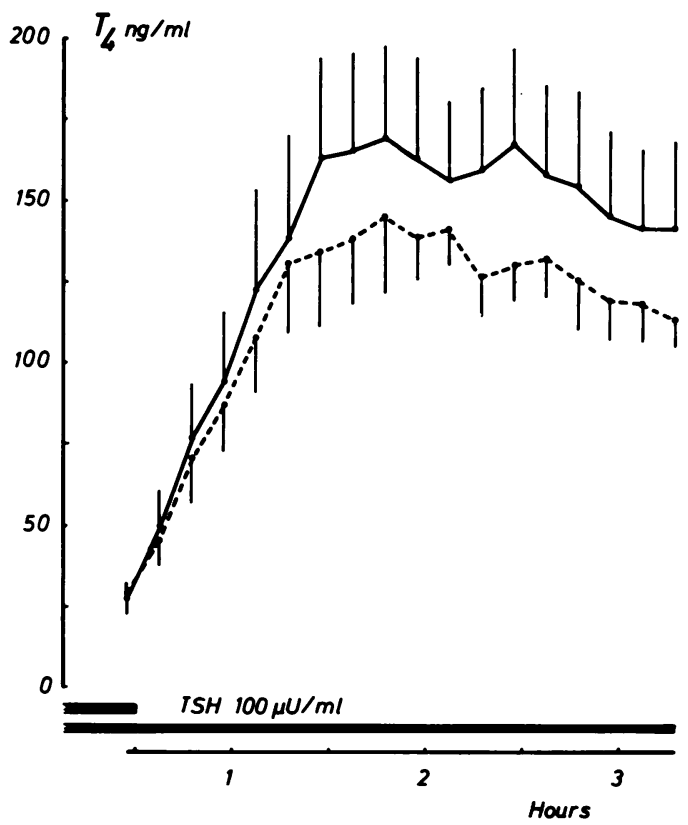

FIGURE $1 \mathrm{~T}_{4}$ in effluent from dog thyroid lobes during oncethrough perfusion. In each dog both of the two separate lobes were perfused independently. Both lobes received $100 \mu \mathrm{U} / \mathrm{ml}$ TSH during the final part of the surgical procedure, $\sim 20 \mathrm{~min}$ before the beginning of the experimental period. One thyroid lobe (-) received control medium after $30 \mathrm{~min}$, when the first sample for determination of iodothyronines had been obtained, whereas the contralateral lobe (-- ) continued to receive TSH during the experimental period. (Mean $\pm S E$, $n=4$ ). 
composition of thyroid effluent, the curves from the two lobes being superimposable.

Thyroid secretion after cessation of cAMP infusion. To exclude a continued stimulation by receptor-bound TSH, a similar series of experiments was made using $5 \mathrm{mM}$ cAMP as stimulator of thyroid secretion. The $\mathrm{T}_{4}$ release in these experiments is shown in Fig. 2. In thyroid lobes receiving cAMP throughout the experimental period, the shape of the $T_{4}$ release curve was similar to that observed during TSH infusion. However, cessation of cAMP infusion induced marked alterations in $\mathrm{T}_{4}$ release, the curve assuming a bell shape. During the first 40 min after cessation of cAMP infusion, the $T_{4}$ release continued to increase, very similarly to that from the contralateral thyroid lobes still receiving CAMP. After $40 \mathrm{~min}$ the curve leveled off, followed by a rapid decrease in $T_{4}$ secretion which then gradually approached a level comparable to that observed from unstimulated thyroid lobes.

Again the $T_{4}: T_{3}$ and $T_{4}: r T_{3}$ ratios in effluent samples were calculated. The $T_{4}: T_{3}$ ratios are depicted in Fig. 3. During continuous infusion of $5 \mathrm{mM}$ cAMP an initial increase in the $T_{4}: T_{3}$ ratio in effluent was observed. This is the late ascending phase of the variation in ratios observed after initiation of stimulation. The full response is depicted in Fig. 4. On the other hand, after cessation of cAMP infusion a much steeper in-

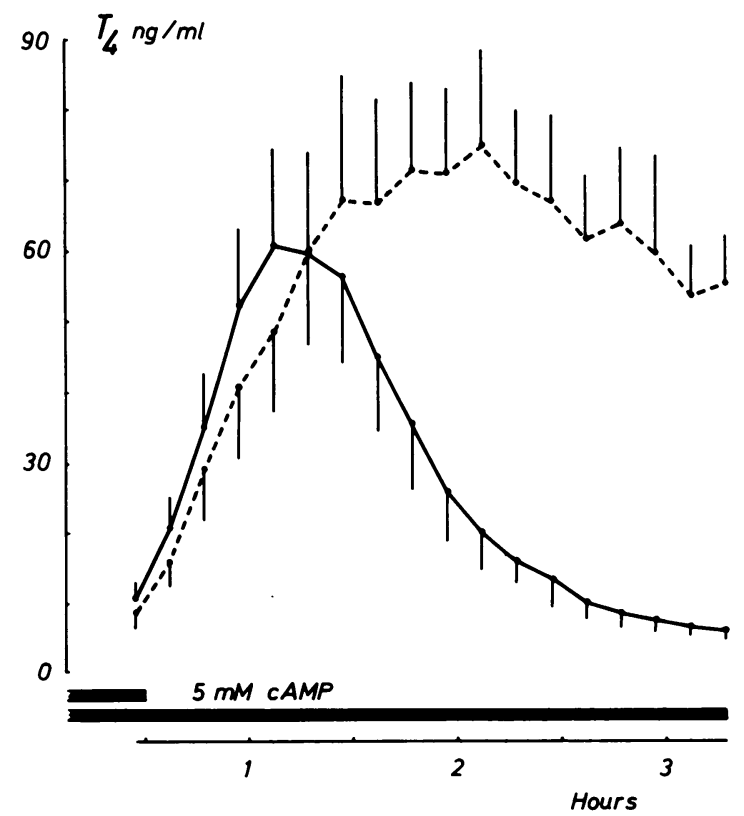

Figure $2 \mathrm{~T}_{4}$ in thyroid effluent in six experiments. The two separate thyroid lobes were perfused independently. Both lobes received $5 \mathrm{mM}$ cAMP during the final part of the surgical procedure and during the first $30 \mathrm{~min}$ of the experimental period. After $30 \mathrm{~min}$ one lobe (-) was perfused with control medium, whereas the other $(---)$ continued to receive cAMP for the entire experimental period. (Mean $\pm \mathrm{SE}$ ).

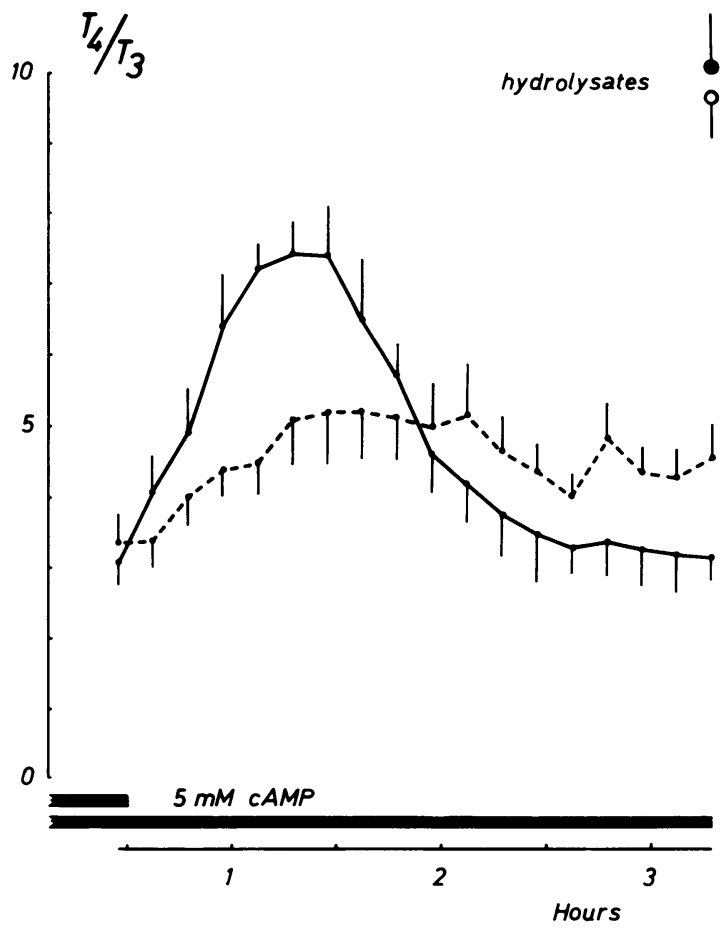

Figure $3 \quad \mathrm{~T}_{4}: \mathrm{T}_{3}$ ratios (wt/wt) in thyroid effluents and thyroid hydrolysates in the six experiments shown in Fig. 2. effluent of thyroid lobes where cAMP infusion was stopped after $30 \mathrm{~min}$; hydrolysate of these lobes. - - - effluent of thyroid lobes continuing to receive cAMP; 9 , hydrolysate of these lobes. (Mean $\pm S E$ ).
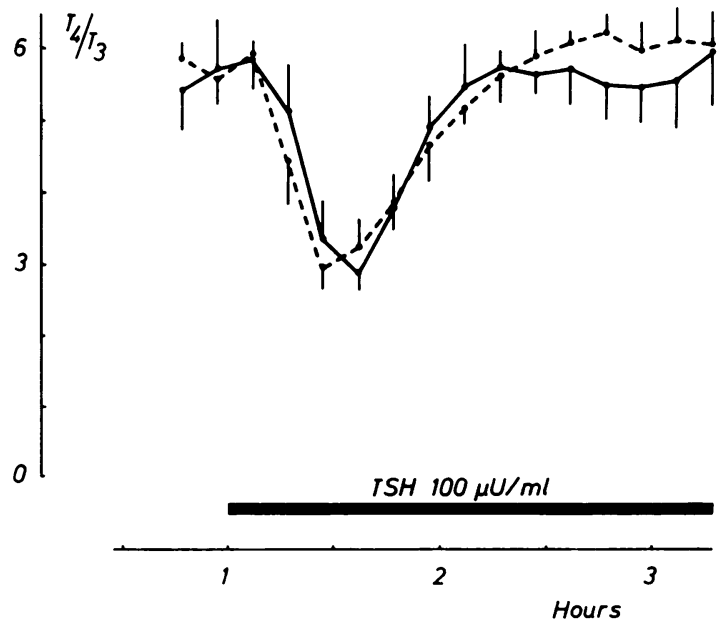

Figure $4 T_{4}: T_{3}$ ratio ( $w t / w t$ ) in thyroid effluent in four experiments where infusion of $100 \mu \mathrm{L} / \mathrm{ml}$ TSH was initiated after $1 \mathrm{~h} . \mathrm{C}^{--}$, ratio calculated directly from the measured $T_{4}$ and $T_{3}$ in effluent. - ratio calculated from the measured $T_{3}$ in effluent and from a calculated $T_{4}$ secretion. The most important assumptions made for calculating this hypothetical $T_{4}$ secretion were that a constant fraction of $T_{4}$ is monodeiodinated to $T_{3}$ during secretion, and $75 \%$ of $T_{4}$ is postponed 20 min relative to $T_{3}$ during release from intracellular thyroglobulin. 
crease in the $T_{4}: T_{3}$ ratio was seen, and at the time that $T_{4}$ release was maximal, and similar to that from the continuously stimulated lobes (Table II, 65-90 min of perfusion), the $T_{4}: T_{3}$ ratio in thyroid effluent was much higher than that in effluent from the contralateral lobes. As it appears from Table II this reflects that the $T_{3}$ release leveled off earlier than the $T_{4}$ release after withdrawal of cAMP and that the $T_{3}$ release from these lobes - when their secretion was maximal - was lower than from the continuously stimulated lobes. During the period with decreasing $T_{4}$ secretion, the $T_{4}: T_{3}$ ratio in effluent also decreased and at the end of the experiment it was lower in the unstimulated than in the stimulated thyroid lobes $(P<0.01)$. The $\mathrm{T}_{4}: \mathrm{T}_{3}$ ratio in thyroid effluent was consistently lower than that of thyroid hydrolysate.

As shown in Fig. 5 the $\mathrm{T}_{4}: \mathrm{rT}_{3}$ ratio in effluent was also significantly enhanced by the cessation of cAMP infusion $(P<0.05$ in the $65-90$-min period of perfusion). However, the effect was less pronounced than on the $T_{4}: T_{3}$ ratio, and even if $\mathrm{rT}_{3}$ release was lower after withdrawal of cAMP infusion in the 65-90-min interval than during continuous cAMP infusion, this was not statistically significant (Table II). This reflects that the coincidental variation in the relative composition of effluent from the two perfused thyroid lobes in

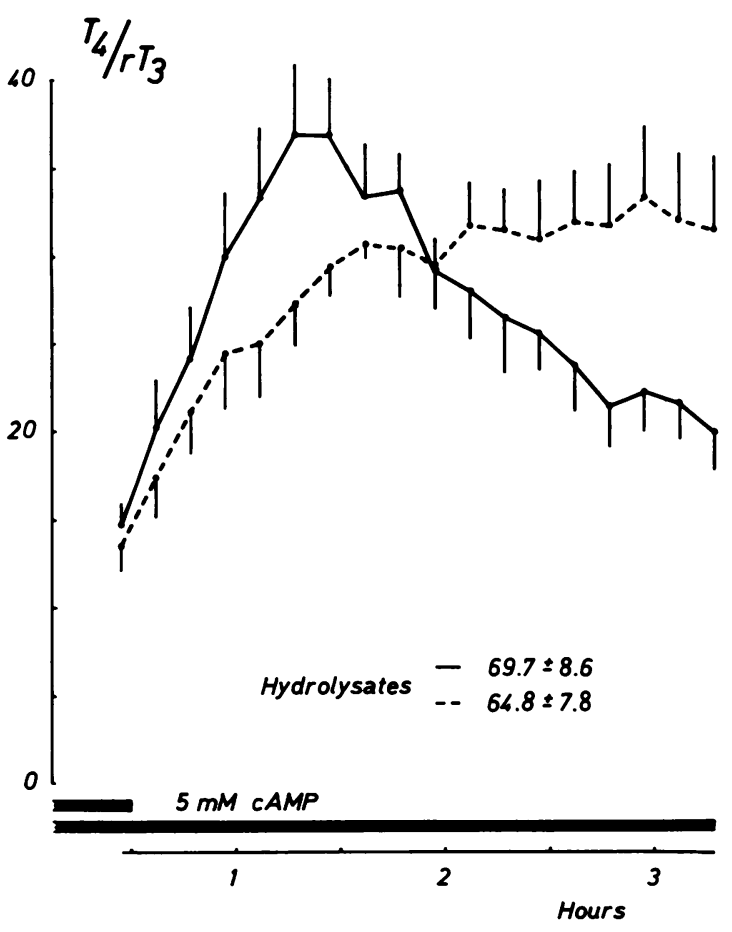

Figure $5 \quad \mathrm{~T}_{4}: \mathrm{rT}_{3}$ ratios (wt/wt) in thyroid effluents and hydrolysates in the six experiments shown in Fig. 2. _-, effluent of thyroid lobes where cAMP infusion was stopped after 30 min. - - - effluent of thyroid lobes continuing to receive cA.MP. (Mean \pm SE). a dog is less than the coincidental variation in absolute release of iodothyronines. When thyroid secretion declined, a fall in the $\mathrm{T}_{4}: \mathrm{rT}_{3}$ ratio occurred. At the end of the experiment it was statistically significantly lower in effluent from unstimulated than from cAMPstimulated thyroid lobes $(P<0.01)$.

Hypothetical $T_{4}: T_{3}$ variation assuming a delay in $T_{4}$ release. It was natural to search for a common mechanism for the transient increase in the $T_{4}: T_{3}$ and $\mathrm{T}_{4}: \mathrm{rT}_{3}$ ratios in thyroid effluent after termination of stimulation, observed in the present study, and the transient decrease in the same ratios in effluent after initiation of stimulation, observed in previous studies $(1-3,8)$. One possible mechanism was that $\mathrm{T}_{3}$ and $\mathrm{rT}_{3}$ in intracellular thyroglobulin in some way is released faster than $T_{4}$. To see whether such a mechanism may fit the experimental data obtained using the perfused canine thyroid, and to get an idea of the delay in $\mathrm{T}_{4}$ release necessary for inducing the observed variation, we took the liberty of including some calculations of a hypothetical variation in effluent $T_{4}: T_{3}$ using data from a previous study where a control perfusion period was followed by a TSH stimulation (3). Hypothetical curves for $T_{4}: T_{3}$ in thyroid effluent were calculated using various delays in various fractions of $\mathrm{T}_{4}$. Fig. 4 shows the calculated variation in $T_{4}: T_{3}$ in effluent assuming that $25 \%$ of $\mathrm{T}_{4}$ and all $\mathrm{T}_{3}$ in thyroglobulin engulfed for hydrolysis was secreted at equal rates although the release of $75 \%$ of $\mathrm{T}_{4}$ was postponed $20 \mathrm{~min}$. Further, the mean $T_{4}: T_{3}$ curve actually observed in the experiments is shown. As can be seen, by using this delay in $\mathrm{T}_{4}$ secretion for calculation, the hypothetical and the experimental curves are practically identical.

\section{DISCUSSION}

No discernible alteration in thyroidal secretion was observed during a period $>2.5 \mathrm{~h}$ after termination of TSH administration. The prolonged effect of TSH is compatible with a slow release of receptor-bound TSH $(9,10)$. To circumvent the continued stimulation of colloid uptake by receptor-bound TSH, $5 \mathrm{mM}$ cAMP was used as a stimulator. This dose induced a considerable increase in secretion in our preparation, whereas concentrations of cAMP $<1 \mathrm{mM}$ had no effect (8). The half-life of endogenous cAMP in stimulated dog thyroid cells has been calculated to be $1 \mathrm{~min}$ and $50 \mathrm{~s}$ (11). If exogenous cAMP is metabolized similarly in the present experiments, it would be expected that intracellular CAMP should fall below the stimulatory threshold $\sim 5 \mathrm{~min}$ after the termination of cAMP infusion. Indeed, when cAMP infusion was terminated a very different pattern of secretion was observed. $\mathrm{T}_{4}$ release continued unaffected for $\sim 40 \mathrm{~min}$, then it leveled off and gradually declined.

The secretory patterns seen after withdrawal of TSH 
and cAMP infusion are in keeping with previous studies suggesting that stimulation of thyroid secretion continues for some time after cessation of $\mathrm{TSH}$ administration as a result of persistent activity of bound, biologically active TSH (12-15); and even after that, increased secretion may continue for a certain period because of hydrolysis of intracellular thyroglobulin $(14,16)$.

Using the same preparation we previously demonstrated that $\mathrm{T}_{3}$ and $\mathrm{rT}_{3}$ are secreted preferentially to $T_{4}$, i.e., the $T_{4}: T_{3}$ and $T_{4}: \mathrm{rT}_{3}$ ratios are consistently higher in thyroid hydrolysate than in thyroid effluent $(1,3)$. This difference is at least partially the result of intrathyroidal monodeiodination of $\mathrm{T}_{4}$ to $\mathrm{T}_{3}$ and $\mathrm{rT}_{3}$ (7). In the present study our previous finding of a preferential secretion of $\mathrm{T}_{3}$ and $\mathrm{rT}_{3}$ was confirmed. However, the most interesting observation concerning the relative composition of thyroid secretion was that after termination of CAMP infusion the induced augmentation of $T_{4}$ release persisted longer than that of $\mathrm{T}_{3}$ and $\mathrm{rT}_{3}$, leading to a transient increase in the $\mathrm{T}_{4}: \mathrm{T}_{3}$ and $\mathrm{T}_{4}: \mathrm{rT}_{3}$ ratios in the effluent.

Previous studies dealing with the secretory dynamics during the early stimulatory phase have shown exactly the opposite pattern of variation of the $T_{4}: T_{3}$ and $\mathrm{T}_{4}: \mathrm{rT}_{3}$ ratios i.e., a transient decrease $(1-3,8)$. Three alternative mechanisms for the phenomenon were envisaged. (a) enhanced $T_{4}$ monodeiodination to $T_{3}$ and $\mathrm{rT}_{3}$. This is unlikely because the phenomenon is not inhibited by propylthiouracil (17). (b) an initial preferential ingestion of thyroglobulin relatively rich in $\mathrm{T}_{3}$ and $\mathrm{rT}_{3}$, but this seems hardly probable in view of the opposite variation in $\mathrm{T}_{4}: \mathrm{T}_{3}$ and $\mathrm{T}_{4}: \mathrm{rT}_{3}$ observed after termination of stimulation. (c) we are therefore left with the third possibility; that $\mathrm{T}_{3}$ and $\mathrm{rT}_{3}$ are liberated at a higher rate than $\mathrm{T}_{4}$ from the follicular cells into the circulation. Such a mechanism would explain why the changes in the $\mathrm{T}_{4}: \mathrm{T}_{3}$ and $\mathrm{T}_{4}: \mathrm{rT}_{3}$ ratios only appear when the secretory rate changes.

Using data obtained in a previous study on iodothyronine release from perfused thyroid lobes after initiation of stimulation, we have tried to substantiate this theory using a hypothetical model where the liberation of $T_{4}$ was delayed in comparison with $T_{3}$. It was found that if $75 \%$ of the liberated $\mathrm{T}_{4}$ was delivered to the circulation 20 min later than the remainder of the $T_{4}$ and of $T_{3}$, then the hypothetical $\mathrm{T}_{4}: \mathrm{T}_{3}$ curve was an almost exact replica of the experimental one. It is realized that the thyroxine molecules are hardly treated in such two completely separate entities. It seems more probable that the delays of individual $\mathrm{T}_{4}$ molecules are distributed within a range, in the experiments used for calculation the secretory dynamics happen to be fairly well described by the two populations.
A faster release of $T_{3}$ than of $T_{4}$ could be the result of either a faster liberation of $T_{3}$ from thyroglobulin during intracellular hydrolysis or to a faster transport (or diffusion) of liberated $\mathrm{T}_{3}$ out of the follicular cell into the capillary. Unfortunately, very little is known of the transport mechanism. On the other hand, thyroglobulin hydrolysis has been rather intensively studied, and it is known that various iodinated compounds may be released at different rates during enzymatic hydrolysis (18-23). We have found in preliminary experiments using dog thyroid homogenate that at acid $\mathrm{pH}$, which is presumably also present in intracellular phagolysosomes, larger fractions of $\mathrm{T}_{3}$ and $\mathrm{rT}_{3}$ than of $\mathrm{T}_{4}$ are released during partial autolysis (24). Thus, with our present knowledge it seems most likely that a faster liberation of $\mathrm{T}_{3}$ and $\mathrm{rT}_{3}$ takes place during intracellular hydrolysis of thyroglobulin.

Several factors are responsible for the amount of various iodothyronines secreted from the thyroid in any given situation. The basal factors seem at present to be the iodothyronine content of thyroglobulin; the rate of thyroglobulin uptake in the cells; intrathyroidal iodothyronine deiodinating processes; and differences in the rate of release of various iodothyronines from intracellular thyroglobulin. Other factors such as variations in the activity of hydrolysing enzymes or in the susceptibility of thyroglobulin molecules to hydrolysis could also be involved.

\section{ACKNOWLEDGMENTS}

The expert technical assistance of Karen Mathiassen is gratefully acknowledged.

This study was supported by grants from the Danish Medical Research Council and from the University of Aarhus.

\section{REFERENCES}

1. Laurberg, P. 1976. $T_{4}$ and $T_{3}$ release from the perfused canine thyroid isolated in situ. Acta Endocrinol. 83: 105-113.

2. Laurberg, P. 1977. The relative contribution of thyroxine and triiodothyronine to the hormone secretion from the perfused canine thyroid during various degrees of stimulation. Endocrinology. 100: 656-662.

3. Laurberg, P. 1978. Non-parallel variations in the preferential secretion of $3,5,3^{\prime}$-triiodothyronine $\left(\mathrm{T}_{3}\right)$ and $3,3^{\prime}, 5^{\prime}-$ triiodothyronine $\left(\mathrm{rT}_{3}\right)$ from dog thyroid. Endocrinology. 102: $757-766$.

4. Inoue, K., and A. Taurog. 1967. Digestion of ${ }^{131} \mathrm{I}-$ labeled thyroid tissue with maximum recovery of ${ }^{131} \mathrm{I}-$ iodothyronines. Endocrinology. 81: 319-332.

5. Weeke, J., and H. Orskov. 1978. Evaluation of thyroid function. In Recent Advances in Clinical Biochemistry. K. G. M. M. Alberti, editor. Churchill Livingstone, Edinburgh. 1: 111-128.

6. Weeke, J., and H. Ørskov. 1975. Ultrasensitive radioimmunoassay for direct determination of free triiodothyronine concentration in serum. Scand. J. Clin. Lab. Invest. 35: 237-244. 
7. Laurberg, P. 1978. Selective inhibition of the secretion of triiodothyronines from the perfused canine thyroid by propylthiouracil. Endocrinology. 103: 900-905.

8. Laurberg, P. 1978. Dynamics of hormone release from the perfused canine thyroid during cyclic AMP infusion. Horm. Metab. Res. 10: 152-155.

9. Manley, S. W., J. R. Bourke, and R. W. Hawker. 1972. Reversible binding of labelled and non-labelled thyrotrophin by intact thyroid tissue in vitro. J. Endocrinol. 55: 555-563.

10. Verrier, B., G. Fayet, and S. Lissitzky. 1974. Thyrotropinbinding properties of isolated thyroid cells and their purified plasma membranes. Relation of thyrotropinspecific binding to adenylate-cyclase activation. Eur. J. Biochem. 42: 355-365.

11. Van Sande, J., S. Swillens, and J. E. Dumont. 1977. Adenosine $3^{\prime}: 5^{\prime}$-monophosphate metabolism and turnover in dog thyroid slices. Eur. J. Biochem. 72: 241-246.

12. Pastan, I., J. Roth, and V. Macchia. 1966. Binding of hormone to tissue: the first step in polypeptide hormone action. Proc. Natl. Acad. Sci. U. S. A. 56: 1802-1809.

13. Van Sande, J., and J. E. Dumont. 1973. Effects of thyrotropin, prostaglandin $E_{1}$ and iodide on cyclic $3^{\prime}, 5^{\prime}$ AMP concentration in dog thyroid slices. Biochim. Biophys. Acta. 313: 320-328.

14. Malan, P. G., J. Strang, and W. Tong. 1974. TSH initiation of hormone secretion by rat thyroid lobes in vitro. Endocrinology. 95: 397-405.

15. DeRubertis, F. R., R. Chayoth, U. Zor, and J. B. Field. 1975. Evidence for persistent binding of biologically active thyrotropin to thyroid in vitro. Endocrinology. 96: $1579-1586$.

16. Unger, J., J. M. Boeynaems, P. Ketelbant-Balasse, J. E. Dumont, and J. Mockel. 1978. Kinetics of dog thyroid secretion in vitro. Endocrinology. 103: 1597-1604.

17. Laurberg, P. The effect of propylthiouracil on TSH induced alterations in iodothyronine secretion from perfused dog thyroids. Biochim. Biophys. Acta. In press.

18. Roche, J., G-H. Deltour, S. Lissitzky, and R. Michel. 1950. Sur les constituants iodes de la thyroglobuline marquee et leur liberation au cours de l'hydrolyse trypsique. C. R. Soc. Biol. 144: 1321-1323.

19. Tong, W., and I. L. Chaikoff. 1958. Hydrolysis of $\mathrm{I}^{131}$. thyroprotein by pancreatic enzymes. J. Biol. Chem. 232: 939-950.

20. Pitt-Rivers, R., and R. R. Cavalieri. 1963. The free iodotyrosines of the rat thyroid gland. Biochem. J. 86: 86-92.

21. Kobayashi, I., and M. A. Greer. 1971. Studies on the enzymatic hydrolysis of peptide-bound iodoamino acids. Endocrinology. 88: 309-317.

22. Inoue, K. 1968. Specificity of proteolytic enzymes in the release of $\mathrm{T}_{4}$ and $\mathrm{T}_{3}$ from ${ }^{125}$ I-labelled thyroglobulin. Program of the Forty-fourth Meeting of the American Thyroid Association. 61.

23. Kobayashi, I., and M. A. Greer. 1970. Effect of $\mathrm{pH}$ during enzymatic digestion of thyroglobulin (Tgb) on the liberated $\mathrm{T}_{3} / \mathrm{T}_{4}$ ratio. Program of the Fifty-second Meeting of the Endocrine Society. 103.

24. Laurberg, P. 1978. Thyroglobulin hydrolysis and variations in secretion rates of $T_{3}$ and $T_{4}$ from the perfused canine thyroid. Ann. Endocrinol. (Paris). 39: 33A. 